\title{
Evaluación de los beneficios y desventajas de los cultivos de cobertura en el uso de pastos naturales, hacienda San Rafael, Santo Domingo Ecuador.
}

Evaluation of the benefits and disadvantages of cover crops in the use of natural grass, hacienda San Rafael, Santo Domingo Ecuador.

Byron Fabricio Estupiñán Cox. ${ }^{1}$, Patricio Alejandro Merino Córdova. ${ }^{2}$, Shakespeare Agustín Abarca Córdova. ${ }^{3} \&$ Daniel Eriel Izquierdo García. ${ }^{4}$

Recibido: 10-10-2018 / Revisado: 17-11-2018 /Aceptado: 04-12-2018/ Publicado: 05-01-2019

\begin{abstract}
.
DOI: $\underline{\text { https://doi.org/10.33262/cienciadigital.v3i1.276 }}$

A recent study illustrates the benefits of using cover crops against erosive phenomena, to maintain soil fertility, allow greater infiltration and storage of water in the soil.

The use of repeated surface works as a method to manage the olive grove between rows, for the control of weeds and for the conservation of water, leads in the long term to a reduction of the organic substance, to problems of soil compaction underneath. The superficial layer. And the loss of soil and fertility due to erosion, the risk of which increases in mountainous olive groves.

The sustainable alternative is constituted by the practice of pasture, which, if properly achieved to minimize competition with the olive, offers several advantages both in the reduction of soil losses and in water conservation, as well as in the maintenance of fertility, the mineral. And biological. In addition to the management of a natural lawn, inter-row grass can also be achieved through the planting of mixed meadows or specific cover crops (cover crops).
\end{abstract}

Keywords: Organic substance, Fertility, Mineral

\footnotetext{
${ }^{1}$ Universidad Técnica Luis Vargas Torres, Esmeraldas, Ecuador, byrondj627@hotmail.com

2 Universidad Técnica Luis Vargas Torres, Esmeraldas, Ecuador, patric_merino@hotmail.com

${ }^{3}$ Universidad Técnica Luis Vargas Torres, Esmeraldas, Ecuador, shak63@ hotmail.es

${ }^{4}$ Universidad Técnica Luis Vargas Torres, Esmeraldas, Ecuador, jones_izquierdo23@hotmail.com
} 


\section{Resumen.}

Un estudio reciente ilustra los beneficios de usar cultivos de cobertura contra fenómenos erosivos, para mantener la fertilidad del suelo, permitir una mayor infiltración y almacenamiento de agua en el suelo.

El uso de trabajos de superficie repetidos como un método para manejar el olivar entre hileras, para el control de las malezas y para la conservación del agua, conduce a largo plazo a una reducción de la sustancia orgánica, a problemas de compactación del suelo debajo. La capa superficial. Y la pérdida de suelo y fertilidad debido a la erosión, cuyo riesgo aumenta en los olivares montañosos.

La alternativa sostenible está constituida por la práctica del pasto, que, si se logra apropiadamente para minimizar la competencia con el olivo, ofrece varias ventajas tanto en la reducción de las pérdidas de suelo y en la conservación del agua, como en el mantenimiento de la fertilidad, el mineral. Y biológico. Además del manejo de un césped natural, el césped entre hileras también se puede lograr a través de la siembra de prados mixtos o cultivos de cobertura específicos (cultivos de cobertura).

Palabras clave: Sustancia orgánica, Fertilidad, Mineral.

\section{Introduction}

Not all herbaceous crops are suitable for use as cover crops, and some are more suitable for reducing erosive phenomena in olive groves: they have illustrated this in a recent publication (Ruibérriz de Torres, 2018), some researchers have compared four botanical species sown in the row of olive trees with a control not worked (worked) or with a spontaneous grass. The selected and sown species in the autumn were a gramineae, Brachypodium distachyon (twopeaked brachipodio), a crucifer, Sinapis alba (white mustard) and two species of nitrogenfixing legumes, Vicia sativa (common vetch) and Vicia ervilia (vecciola)).

\section{Coverage Crops}

Some herbaceous species (mainly belonging to legumes, grasses and cruciferous families) can be cultivated as intermediate layers (in the period between two main crops in rotation) to conserve or increase the physical, chemical and microbiological fertility of agricultural lands.

Its main function is to bring organic substances to the system through the organization of $\mathrm{CO} 2$ and nutrients, present in the soil at a time of year when the soil would be free of vegetation (inter-crop period).

In general, the presence of a vegetation cover during the intercropping period or during the vegetative stasis of the crop, main (arboretum), can offer the following advantages: 
1. Increase in content in S.O. from the earth

2. Improvement of the structure of the land.

3. Improvement of water infiltration.

4. Improvement of the traficabilidad.

5. Control of water and wind erosion (reduction of surface flow, outputs).

6. Control of weed flora.

7. Increase of biological diversity within the agroecosystem.

8. Absorption of nitrates and other nutrients that are otherwise lost through leaching or sliding of the surface

9. Better nutrient cycle

10. Possible increase in the availability of nutrients for crops in succession and disadvantages:

10.1. The competition with the main culture.

10.2. Reduction of water availability.

10.3. Possible reduction of nutrient availability (immobilization of nitrogen)

10.4. Allopathic effects

10.5. Increase in variable costs

The advantages and disadvantages offered by this type of culture depend on the "position" assumed within of the rotation, by the species (or species) used and by the "management" of the cover crop. Regarding the first aspect (positioning of crop crops in the rotation, crops of the Coverage can be divided into two groups: permanent or temporary.

The permanents are found mainly in the field of tree crops, as in the case of the grazing of the garden; In this case, the positive effects of the vegetal cover are essentially due to a greater control, of the phenomena of the water and wind erosion, to a better traffic of the plots, less compaction of the soil, increase of S.O., control of the infesting flora in the inter-row, potential absorption of nitrogen, free of lye, supply of nitrogen in the case of cover crops of legumes.

The advantages and disadvantages offered by this type of culture depend on the "position" assumed within of the rotation, by the species (or species) used and by the "management" of the cover crop. Regarding the first aspect (positioning of crop crops in the rotation, crops of the Coverage can be divided into two groups: permanent or temporary.

The permanents are found mainly in the field of tree crops, as in the case of the grazing of the garden; In this case, the positive effects of the vegetal cover are essentially due to a greater control, of the phenomena of the water and wind erosion, to a better traffic of the plots, less compaction of the soil, SO increase, control of the infesting flora in the inter-row, potential nitrogen absorption, free of bleach, nitrogen supply in the case of legume cover crops. The main perplexities related to the grass, the arboretums they derive from the possible forms of competition that the cover crop can exercise against that Principal, especially as regards soil 
moisture. To avoid phenomena of this type, in the absence of irrigation, it would be necessary to direct the choice of the species or mixture towards perennial plants characterized by a vegetative stasis synchronous with that of greater sensitivity to water stress of the main crop (Trifolium subterranean L.) or that it reduces or suspends its vegetative development in correspondence with the period of maximum water demand of the garden (Trifolium repens L., Lolium perenne L., Festuca spp., etc.).). Regarding the problem of costs, this goes back to basically for the preparation of the seedbed and for the purchase of the seed, since the possible control of the husk, the grass could imply costs similar to those of working the arboretum. The problem of sowing and seed. They could be overcome by the use of selfexpanding species.

The temporary coverings of plants, on the other hand, occupy the land for a relatively short period of time, among other things, greater dynamism within the same change. These in turn can be divided into intercultural and coordinated.

\section{Soil erosion}

Erosion is a physical process responsible for continuous remodeling of the earth's surface.

Determines the removal of material from the surface of the soil. In ecosystems not altered by man, erosion is one.

Natural phenomenon that accelerate human activities. To cause a progressive degradation of fertility and therefore of the potential productivity of the soil.

Erosion is a complex process influenced by numerous factors such as climate, soil type, landscape forms, hydrology, vegetation and crops.

Processing and cultivation systems. These factors are related to each other and capable of determining, in different measures, the extent of the erosive process and its variations in space and time.

Depositions of eroded material can block roads. And drainage channels. Sediments can damage natural habitat and degrade the quality of surface water. According to some authors in the case of cover crops built to keep the land covered during the year, autumn-winter, where technically possible, it is preferable to transcribe them in the previous crop, in such a way that the "cover crop" can reach proper rooting and, therefore, a good degree of coverage already. Immediately after the collection operations.

\section{Coverage cultivation functions}

The soil in nature is always covered, that is, covered. The bare soil, without grass, leaves other living or decomposing material that does not exist naturally. If a land is completely 
bare, it is not alive, as it happens in the desert or in rocky areas. From this simple observation we understand that if we want to grow our edible plants in the most natural way possible, we must cover the soil. Coverage has many functions:

Protects the earth (and its inhabitants) from excessive heat or cold, limits evaporation and, therefore, maintains moisture for longer, delays the growth of spontaneous plants by stopping the passage of light necessary for its growth, prevents the compaction of the earth when it rains. These are the main reasons why mulch is used, a common practice even in intensive production (perhaps made with synthetic materials), but they are not the most important. The organic matter of the surface nourishes the multiplicity of micro and macro organisms that, with their work, is transformed into assailable food by the plants. In practice, it allows the fertility cycle to be carried out, without this process, the soil would become impoverished until death. But it did not end here. The organic matter is also a powerful sponge that, when it rains, is soaked in water and then released slowly, which allows it to reach the underground aquifers. Without this mantle, also made of humus and roots, the water could not seep into the earth and would slide quickly by dragging behind several elements. Thus the earth becomes impoverished and thus the desert is formed. The muddy rivers that rush towards the sea, sometimes destroying the works of man and taking lives, would not exist without the transformations that man has brought to the planet throughout the millennia, especially with agriculture. You can not imagine returning to a primordial phase of the Earth, not even wanting it. But much can be done if one understands some essential needs of nature: the land wants to be covered. Then, when we look at a beautiful field freshly plowed and sown in which we can not see a blade of grass, neither alive nor dead, we are not admiring the beginning of a new cycle of life, but the sure premise of the destruction of the greatest inheritance land. Fertile soil suitable for life.

\section{Cover crops or intermediate crops.}

Practices that foresee the next crop or intermingling with rapid growth and sowing with a high density of legume species, or less, to reduce soil and nutrient losses (such as nitrogen and other fertilizer elements). The crop in general has no economic interest and can be buried before planting the one that has economic interest.

\section{The relationship with parasites.}

Keeping the ground covered with a green manure crop has several advantages, but it can also cause unexpected problems. He has faced them, thanks to his experience in the States, Richard Edwards, of the Purdue University of Lafayette, Indiana. "The crop coverage can harbor several insects, some of which can be harmful to the income crops that we will plant later," the teacher explained. In essence, they could create a hospitable environment for some pests that later, after the cover crop, would move on corn or wheat, with foreseeable damages. 
On the other hand, it is also possible that cover crops provide hospitality to insect's predators of parasites or that they have a deterrent effect towards unwanted species. "Good roof management, therefore, can significantly reduce the potential for adversity and favor beneficial species," said the teacher. Among the harmful species, the speaker cited Lepidoptera, slugs, insects and other sucking insects, phytophagous mites, aphids and thrips. "All these parasites can cause problems, especially if the main crop follows a period of coverage of a few days, which is why I always recommend waiting two weeks between the conclusion of the cover crop and the next planting, even if I realize that this waiting time can be a problem if you are in a hurry to plant.

In general, underlined Edwards, it is important to understand which species are kept in cover crops and what effect they may have on the following. "Naturally, considering what income crops will be sown and what species we want to preserve." A typical case is that of the noctuids, whose females are not attracted to corn, but they like to lay their eggs in dicotyledonous broadleaf. If we use these plants as a cover crop and shortly after planting the corn, the noodles, although reluctantly, could migrate from the cover crop to corn, and clearly we will have forced them to this choice ".

Another aspect to keep in mind is that crop covers help keep the soil moist. "We must take this fact into account when we sow the main crop, because it is more difficult to close the furrow in the humid soil and put the seed in an open furrow exposes it to the attacks of slugs and arthropods." In addition, greater humidity can favor fungal diseases, even more insidious than parasitic insects. "The development of a fungal pathology requires a host plant, a pathogen and particular environmental conditions, therefore, the presence of abundant crop residues can contribute to create the right climate, but it is also true that rotation reduces the risk of infections. It is necessary to know well the sensitivity of the essences that we use as a cover crop and the plants that we will cultivate later and to understand if the former can represent a threat to the latter. In addition, it is important to have an interval of approximately two weeks between the crops; it is the right time to solve all these problems. As we say in the United States, you can not sow, weed and go to Florida.

\section{A direct experience}

A "farmer" who certainly does not go to Florida after planting is Cameron Mills, owner of 1,400 hectares in Indiana. On her land, not irrigated or drained, Mills plants the corn, soybeans and wheat in rotation and has left the plow for 15 years, while nine crops of practice cover. "I did it, he explained during the conference, to increase the capacity of water retention, break the process created over the years, increase the rate of organic matter in the soil, recover nutrients and contain weeds. In addition, of course, to stimulate the biological activity in the soil. "Objectives that have been reached to a large extent. « As for the storage of water, in my land, each processing step leads to evaporation of approximately $31 \mathrm{~mm} / \mathrm{ha}$ 
the presence of waste, on the contrary, contrasts evaporation and keeps the soil cooler in the summer. It also improves the structure of the soil, as is known, and increases its porosity.

However, the management of the cover crop (of which Mills has provided an interesting recipe for 15 essences that we publish) must be accurate. "Some varieties outperform winter and require a high level of management. You must choose them according to your equipment and the supposed completion program. In addition, if we decide to eliminate weeds, the treatment should be done with a vital plant and in the hottest hours of a sunny day, so that the effect of the product, such as glyphosate, is maximum.

The use of cover crops, during the periods between one crop and the next, offers a soil cover that can perform many functions: reduce the risks of erosion, nitrogen absorption, limited leaching, and fight against weeds, improve soil fertility, floor etc.

For the cover crops, theoretically you can choose many species, but in practice only a small number (mainly mustard and phallus) is used. In this sense, we are also investigating the potential of numerous species depending on the services of desired agro systems, as well as how to process combinations of species.

\section{How to improve the soil with cover crops?}

The production of organic matter is an important issue for the rural producer. Soil preparation techniques, such as roasting, and planting cover crops that increase soil quality can help or even decrease agricultural yield.

American producer Dave Legvold, of Northfield, in the state of Minnesota, discovered this balance when he took over the administration of a farm 13 years ago.

The area leased by him was heavily cultivated and poorly drained. "It was horrible," says the producer. Legvold, an advocate of band cultivation, wanted to improve the overall quality of the field. This implemented measures that increased organic matter from $1.7 \%$ to $5.5 \%$ and up to $6.5 \%$ in some areas.

According to Chad Watts, executive director of the Conservation Technology Information Center, each floor is different. "We have to treat them case by case," says Watts. In general, Watts suggests less physical disturbance and more plant diversity. "The more organic matter we have, the better advantages we will have," says Chad Watts, executive director of the Conservation Technology Information Center.

Soil receives many benefits from organic matter, says Watts. Proper cultivation and practices that guarantee healthy soil accentuate the benefits. "You can make the cultivation more efficient with a healthy soil, because it is possible to work the air and water more efficiently," says Watts. The first measure that producer Legvold adopted was to improve drainage. "The 
previous official worked with an unusual hydrology with an aiveca plow, going through the grower in the fall," says Legvold.

According to Watts, moisture can limit the soil. And drainage, if properly adopted, is a good technique for the agricultural system. "There is a very productive land that needs soil preparation," he says. With the drainage, the producer Legvold manages to start the crop earlier. "You do not have to wait for the puddles to dry out," he says. Reducing soil preparation is the next step in the Legvold equation. Soil preparation incorporates organic matter and causes volatilization. This causes the matter to suffer combustion and to become atmospheric carbon.

The preparation injects air into the soil. In the fall, when the air leaves the ground, preparation is again necessary. "It's not a healthy cycle, the more preparation you do, the more preparation is necessary," says Watts. According to Watts, fifty percent of the soil should consist of air and water, while the other $50 \%$ should be organic matter. "If $75 \%$ is of soil matter, you have no porosity to move air and water, and as you create porosity, you can move them," he says.

Although Watts advocates less soil changes, he believes that direct seeding should not be the rule for all farms. "There are management techniques that should be done on different soils, but there are many places that we do not need to use direct seeding," he says. After the transition, the soils may not be efficient in the movement of air and water. With fewer changes you can also improve drainage, explains Legvold. "If you are patient and allow the soil to develop, you will have added stability," says the producer. "I can use the planter because the soil is solid while other people can not." There is potential to reduce the application of nutrients, but that does not happen immediately. "With cover crops, we can change the way we think about the nutrition strategy," says Watts. This management favored the nutritional plan created by Legvold. In addition to inserting nutrients through the roots, you also see the benefits of the soil. "In the past, I had to put a lot of fertilizer to produce," he says. "The yield increases as the soil improves," says Legvold.

Now that the quality of the crop has improved, you can count on the recycling of soil nutrients and use up to $30 \%$ less fertilizer. Coverage is another practice that helps in the production process of organic matter, improving soil quality and fertility. Another advantage is that Legvold is saving fuel because, with the reduction of soil preparation and less need for nutrients, it has made fewer fertilizer applications during harvest.

Genetic improvement, advances in the management of pests and diseases, better fertilizer management and new technologies boost productivity. So, many times the problems caused by inadequate soil management practices may go unnoticed. "There is a phenomenon of masking the loss of productivity due to the decrease in soil quality," says Legvold. "If the quality of the soil continues to decrease due to the preparation, we will soon reach a point where we can not overcome the loss of productivity, no matter the strategy." 
According to Watts, all management practices have associated implications. Therefore, it is recommended that there be a systems approach that promotes adaptations in all areas of the farm, with integrated work. "It's a domino effect," says Watts.

Effective but rejected cover crops

\section{Coverage crops and water balance of the earth, Observation "Finca San Rafael Santo Domingo Ecuador"}

In the event that the residues of the cultivation culture are dried or devitalized to remain in soil (arboretum or non-processing systems), they can, in drought environments, help limit evaporation losses and conservation of soil moisture for a longer period of time during the summer.

Table. One

Soil humidity at $30 \mathrm{~cm}$ depth in relation to different plant coverings: \% dry weight LM: minimum processing; NL: not processing

\begin{tabular}{llll}
\hline centeno & $16,2 \mathrm{en}$ & $16.0 \mathrm{ab}$ & $18,0 \mathrm{en} 18.3 \mathrm{ab}$ \\
\hline Vicia villosa & $12.7 \mathrm{~b}$ & $14.6 \mathrm{c}$ & $17.1 \mathrm{ab} 17,0 \mathrm{bc}$ \\
grandiflora Vicia & $11,4 \mathrm{bc}$ & $14.4 \mathrm{c}$ & $15.0 \mathrm{ab} 16.6 \mathrm{c}$ \\
Vicia Vill. + Vicia grandifl. & $11,3 \mathrm{bc}$ & $14.8 \mathrm{c}$ & $17.1 \mathrm{ab} 17,5 \mathrm{bc}$ \\
Vill centeno + Vicia. & 15,0 por & 16.5 & $17.2 \mathrm{ab} 19,5$ \\
suelo desnudo & $11.0 \mathrm{c}$ & $15,3 \mathrm{bc}$ & $13,7 \mathrm{~b} 16.8 \mathrm{c}$ \\
\hline
\end{tabular}

With regard to the reduction of evaporation, this is essentially due to the shade of the vegetable coating the resulting soil and another "barrier" effect of the same biomass towards the water vapor; this effect is, therefore, directly related to the quantity and remain in the soil of crop residues. The latter, in turn, depends on the rate of decomposition of the same waste and therefore on the chemical composition of the biomass (percentage content of lignin and cellulose, in particular), and on the administration of the same and the environmental conditions in which it operates. In this sense, for example, the residues of herbs are much more resistant to decomposition than those of legumes, which has a definitely higher $\mathrm{C} / \mathrm{N}$, (Rice and Smith, 1884), as mentioned above the amount and permanence of crop residues from cover crops. "

With regard to the reduction of evaporation, this is essentially due to the shade of the vegetable coating the resulting soil and another "barrier" effect of the same biomass towards the water vapor; this effect is, therefore, directly related to the quantity and remain in the soil of crop residues. The latter, in turn, depends on the rate of decomposition of the same waste 
and therefore on the chemical composition of the biomass (percentage content of lignin and cellulose, in particular), and on the administration of the same and the environmental conditions in which it operates. In this sense, for example, the residues of herbs are much more resistant to decomposition than those of legumes, which has a definitely higher $\mathrm{C} / \mathrm{N}$, (Rice and Smith, 1884), As mentioned above the amount and the In the Soil is also influenced by the type of technical management of alternation, especially with regard to the choice of the moment of drying of the vegetation cover; In fact, if on the one hand, it may be advantageous to grow the cover crop as long as possible, in order to obtain a greater amount of dry matter (Sullivan, 1991), For another delayed devitalization may involve a significant increase in water used by it and therefore a decrease in soil moisture. This can be an advantage if, in rainy years, you want the land to dry faster and therefore anticipate the planting of the next commercial crop, but under normal meteoric conditions, it can involve serious risks of water stress in the early stages of development of the crop that following permanence of crop residues of cover crops ".

\section{Results of Coverage Cultivation observation}

All cover crops have shown good development potential and good soil cover, even if the latter, but only in the first quarter of turf establishment, is lower than that of natural turf. However, the legume species have demonstrated a capacity to settle and colonize the very high inter row in the second year, with an average ground cover between the vetch and the neighbor of around $90 \%$. Research has shown that runoff has been significantly reduced (about $-77 \%$, on average), compared to worked soil, cover crops and natural grass: in particular, white mustard has been shown to be a particularly interesting because of its ability to develop a very extensive root system, which indirectly increases the permeability of the soil and the conservation of the water reserve in the soil. The species could have an additional interest also for the potential biocide, still under study, towards pathogens such as Verticillium dahliae.

The reduction of runoff has also affected the reduction of soil and organic carbon losses: in particular, both brachypodium and mustard have reduced the loss of soil to almost zero due to erosion in simulations of medium intensity rain events (approximately $18 \mathrm{~mm} / \mathrm{h}$ for 2 or 3 consecutive hours). In all the simulations, the erosive phenomena were reduced even more when the events of artificial rain were carried out after the harvest, due to the mulching effect of the residues that remain in the row. In addition to reducing losses of fertile soil, the use of selected cover crops offers an even more obvious advantage over the use of natural grass, in terms of maintaining inter-row and increasing soil capacity to store water retention. Finally, the use of cover crops also has potential from the point of view of the effect of carbon sequestration and the increase of organic matter in the soil.

(https://inta.gob.ar/documentos/los-cultivos-de-cobertura-disminuyen-la-perdida-de-suelospor-erosion-hidrica-0) 


\section{Conclusions}

- Cover crops help to prevent erosion, because their plant mass prevents the direct impact of the raindrop on the ground, slowing the destruction of aggregates and reducing the speed of surface runoff of water. The vegetal cover produced is anchored to the ground and will not be dragged along with the sediments, as happens with the waste cut by the harvester. Below the surface, their roots favor the cohesion and aeration of the soil and after their decomposition they leave ducts that facilitate the entry of water into deeper layers.

\section{Bibliographic References.}

Rice and Smith. (1884). Coverage Titles. 1-25.

Ruibérriz de Torres. (2018). I scold- 8-35.

Sullivan. (1991). Resources and results analysis of soil crops. 1-100

Orbegoso, A. and Germán, A. Production of pectinase enzymes by Actinomycetos in submerged culture using pectin and orange peel. [Master Thesis in Biotechnology], National University of San Marcos, 2002.

Bae, S. and Shoda, M. Statistical optimization of culture conditions for bacterial cellulose production using Box-Behnken design. Biotechnol Bioeng, 2005, vol.90, no.1, p.2028

Jong Min Lim / et al./. Optimization of medium by orthogonal matrix method for submerged mycelial culture and exopolysaccharide production in Collybia maculata. Applied Biochemistry and Biotechnology, 2004, vol. 119, no. 2 P. 159-170.

Ramnani, P. and Gupta, R. Optimization of medium composition for keratinase production on feather by Bacillus licheniformis RG1 using statistical methods involving response surface methodology. Biotechnol. Appl. Biochem, 2004, vol. 40, p. 191-196.

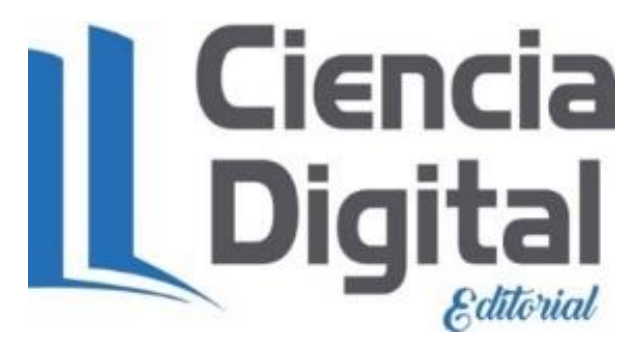




\section{Para citar el artículo indexado.}

Estupiñán B., Merino P., Abarca S. \& Izquierdo D. (2019). Evaluación de los beneficios y desventajas de los cultivos de cobertura en el uso de pastos naturales, hacienda San Rafael, Santo Domingo Ecuador. Revista electrónica Ciencia Digital 3(1), 137-148. Recuperado desde:

http://cienciadigital.org/revistacienciadigital2/index.php/CienciaDigital/article/view/276/66 $\underline{4}$

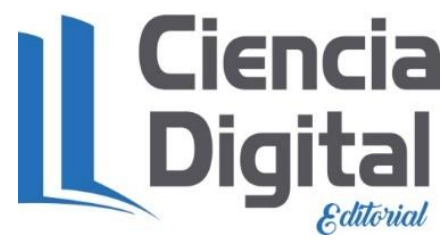

El artículo que se publica es de exclusiva responsabilidad de los autores y no necesariamente reflejan el pensamiento de la Revista Ciencia Digital.

El artículo queda en propiedad de la revista y, por tanto, su publicación parcial y/o total en otro medio tiene que ser autorizado por el director de la Revista Ciencia Digital.
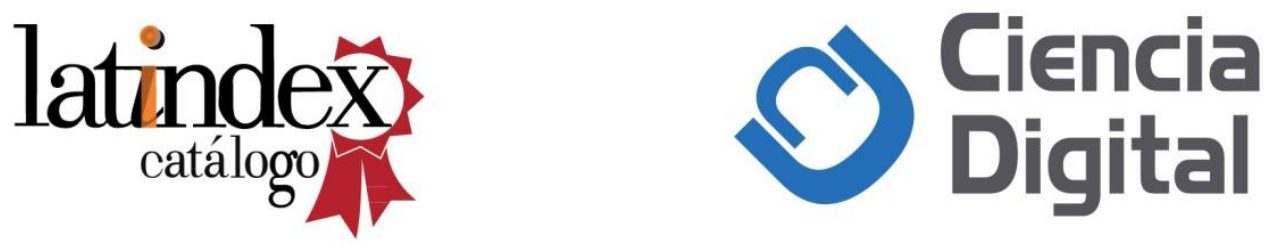